\title{
Evaluating the Use of Kurdish in Efl Classes at Secondary Schools in Duhok City: A Teacher's Perspective
}

\author{
${ }^{1}$ Asma Ameen Hussein, ${ }^{2}$ Hamza Zeebaree \\ ${ }^{1,2}$ English Department, College of Languages, University of Duhok, Duhok- Kurdistan Region of Iraq
}

\begin{abstract}
This study examines the use of first language (L1) in secondary school EFL classes in Duhok city in the Kurdistan Region - Iraq. The use of L1 in EFL classes has been an ongoing debate among researchers and practitioners across the globe especially as regards its role as a facilitator of, or a hinderance/barrier to the teaching of English. Hence, the researcher aims to discover whether or not the use of Kurdish facilitates the teaching of English, in secondary schools in Duhok city. In addition, the researcher aims at finding out on what basis do teachers decide to use L1 and for what purposes do they use it. In this study, among the participants were 50 English language teachers from different secondary schools in Duhok city. The data were collected through interviews. The results indicated that the use of L1 (Kurdish) facilitates teaching of foreign language (FL) and that a balanced and judicious use of L1 in the EFL classroom by teachers can be useful in the language learning process especially with regard to grammar and vocabulary instruction.
\end{abstract}

Keywords: First language, foreign language, mother tongue, English as a foreign language, English language teaching, secondary school.

\section{Introduction}

English language teaching (ELT) has changed over the centuries in relation to the use of first language (L1), and in each class teachers constantly make decisions on the way of teaching. Foreign language (FL) teachers also confront the dilemma of whether to use L1 in English as a foreign language (EFL) classes or to avoid using it all together in order not to affect the learning of the target language (TL). Although in the past the use of both languages was emphasized in the classroom, nowadays a more complex approach to foreign language teaching (FLT) prevails as a number of studies have been conducted which either support or oppose the use of L1 in an EFL classroom.

According to numerous foreign studies examples, the use of mother tongue (MT) in FLT practice differs in different ELT contexts. However, there is an evident lack of similar study and research dealing with this issue in Kurdistan educational context especially in secondary schools. Therefore, the current study attempts to fill this gap. It is of utmost importance to examine the current situation in Duhok secondary schools taking into account that English has an important role to play when the students reach university level where English is used as the medium of instruction and the materials are in English in most of the colleges at university.

Pokharel (2001) stated that "first language, mother tongue and native language are common terms for the language which a person acquires first in his childhood because it is spoken in the family and/or it is the language of the country where he is living". Accordingly, the first language a child learns to use is considered the L1. In the present study, the terms 'mother tongue', 'first language', and 'native language/tongue' are all essentially considered the same set of synonyms (although it is possible to argue that there are instances when they mean different things); therefore, these terms will be used interchangeably throughout the work. 
All the participants of this study have Kurdish as their L1, native language, mother tongue (MT); whereas, TL and FL would be used to refer to English as a foreign language (EFL) that is taught in secondary schools.

\subsection{Purpose of the Study}

Little attention has been paid to the use of L1 in the context of the Kurdish EFL classroom, particularly at secondary schools in Duhok city.

This study is conducted in order to examine whether the use of L1 in EFL classrooms in secondary schools facilitates or hinders the learning of TL. The appropriate use of L1 in EFL classes might be beneficial in that it enhances the learning of TL; secondary school teachers may find it useful to use some L1 to explain difficult meaning, vocabulary, grammar, give instructions, etc.

This research is carried out to find out the view of Kurdish teachers towards the use of Kurdish in EFL classrooms at a secondary school level.

\subsection{Research questions}

This study addresses the following questions:

- Does the use of Kurdish in the classroom hinder or facilitate the learning of FL?

- For what purposes do teachers use L1 while teaching English in their classes?

\section{Literature Review}

2.1 General historical background of $\mathrm{L1}$ and EFL teaching

Whether or not language teachers should use students' first language in their second/foreign language classrooms has always been debated, and continues to be in the field of profession.

A several hundred years ago the bilingual teaching approach was the norm; the use of L1 to study the second language (L2) such as Greek and Latin was accepted with the focus of learning being through translation. However, in the 19th century there was a movement towards a monolingual teaching approach due to different factors.

Hawks (2001) stated that the mass migration of people to other countries forced educators to modify their lessons, as small classes that focused on translation changed into bigger classes with students with different first languages. Phillipson (1992) added that the teachers who were teaching in foreign countries supported the notion of the monolingual approach since classes were full of students who had different first languages. This in return urged teachers to base their teaching solely on L2, as learners' L1 was not a tool that could be used in teaching.

The reasons why the use of students' L1 went out of favor and further strengthened the monolingual approach in the 20th century goes well back in history. Originally, it was partly a reaction to the GrammarTranslation method (GTM) that was dominant in the 19th and 20th centuries. The method viewed learning as the means of intellectual development in students for better understanding their L1 literature, depending on translation rather than communication in the target language (TL).

The method which stood against the principles of GTM was the Direct Method; it aimed at oral competence and claimed that languages were best learnt in a way that emulated the "natural" language learning of the child, i.e., with no analysis or translation (Harbord, 1992). This was also later confirmed by the Audio-lingual Method (ALM) (1940s-1960s) which emphasized habit formation. ALM viewed the use of L1 as interference with the establishment of new habits, and thus the use of L1 was to be avoided at all costs.

Krashen (1985) strongly supported and forwarded the argument that L1 should not be used in the classroom. Most educators and researchers would agree that the more English is used, the quicker and better the students learn, or express themselves within their limited 
command of the TL.

The 1970s was the era of Communicative Language Teaching (CLT) which quickly came to dominate modern language teaching. In the last thirty years or so, avoiding the use of L1 has continued in methodologies, in the Total Physical Response (TPR) method as one example.

Lately, there have also been views that the use of L1 in teaching a FL is a common feature of EFL classes worldwide if used judiciously by teachers and learners (Carless, 2001; James, 1998; Odlin, 1989; and Cook, 2001). Many teachers and researchers have begun using students' L1 in EFL classes as they claim it to be a learning tool, which led to the decline of support for an English-only policy, as reflected in Schweers statement (1999) that the use of L1 in the classroom is necessary. Carless (2001) claimed that one of the common features of the EFL world is using L1 in EFL classes, which leads to positive contribution to the learning process. Accordingly, excluding the students' first language in the EFL classroom would take away an important tool of language learning from them, which is unreasonable to do (Macaro, 1997). Harbord (1992) reported that many English as foreign language teachers tried to apply an English-only policy in the classroom, but yet they were unsuccessful.

In a study by Oflaz (2009), in a Turkish context that used two questionnaires with 60 English language teachers and 100 students and interviews with five of the students from the School of Foreign languages in Gaziantep University, the findings revealed that both the teachers and the learners prefer the use of L1 in the classroom as long as it does not hinder the acquisition of L2.

Nazary (2008) conducted a research on students' attitude towards the use of L1 among Iranian University students through observation and interviews. His findings showed that the students had a negative attitude towards the use of L1 in their English lessons.

The use of the mother tongue has also been inspected in Arabic contexts, as Alshammari (2011) investigated the Saudi Arabian university-level EFL learners' and teachers' use of Arabic using questionnaires and interviews. The results proved that $61 \%$ of the learners were in favor of the use of L1; nearly $5 \%$ thought that L1 is useful when giving instructions; while 54\% thought that using L1 should be for explaining new vocabulary. Almost $69 \%$ of the teachers agreed with the students on the use of L1 in EFL classroom. For teachers, 51\% Arabic was most essential to clarify difficult concepts, $25.7 \%$ to explain new vocabularies, $16 \%$ grammar points and only 7.3\% reported that Arabic is useful for giving instructions.

Al-Nofaie (2010) examined the attitudes of teachers and students towards the use of Arabic in EFL classes in a Saudi intermediate girls' school. Three teachers and 30 participants participated in this study and the tools of questionnaires, interviews and classroom observation were used to collect data. The findings showed that teachers and students generally had positive attitudes towards the use of Arabic in the classroom. The participants preferred to use Arabic with beginners and low-proficiency level students and for specific reasons: explaining grammatical terms, introducing new vocabulary and giving exam instructions.

Schweers (1999) conducted a study on EFL students and teachers at his Puerto Rican University in a Spanish context using a questionnaire to investigate their attitudes towards using L1 and L2 in the lesson. He found out that $88.7 \%$ of the students and $100 \%$ of the teachers felt students' language should be used in their English classes because it facilitates teaching and learning. A big percentage of the students (86\%) felt that L1 should be used when it comes to difficult concepts 
and $67 \%$ said their L1 helps them feel 'less lost'. Schweers (1999) concluded that the pedagogical and affective benefits of L1 justify the use of L1 to be limited and judicious.

Another similar research was conducted by Tang (2002) in China with Chinese speakers. On comparing her results with those of Schweers, Tang (2002) said "both studies indicate that the mother tongue was used by the majority of teachers investigated and both students and teachers responded positively toward its use." The research assert that limited and judicious use of L1 in the English classroom can assist in the teaching and learning process, and it does not reduce learners' exposure to TL.

\subsection{Foreign language education in Kurdistan}

The Sunrise programme, by Macmillan Publication (2007), was set as a curriculum in primary and secondary schools in the Kurdistan Region in Iraq (KRI). According to the official website of Sunrise for Kurdistan the course consists of a teacher's book, student's book and an activity book. In addition, CDs produced for Kurdish primary and secondary school students based on the communicative approach accompany the books, thus integrating listening, speaking, reading and writing with an explicit focus on grammatical structures.

Since 2009, the KRI has taken steps to raise primary and secondary education to international standards, the process including the implementation of K-12 curriculum and making education compulsory through 9th grade, unlike before, whereby it was compulsory only up to and through 6th grade. Basic education in Kurdistan is confirmed between grades 1-9, while secondary education is between grades 10-12. Duhok which is a city in Kurdistan follows the same program directed by the Ministry of Education of Kurdistan. The Sunrise series provides each level from 1-12 with a teacher's book, student's book, activity book, and CDs.

\section{Method}

\subsection{Participants}

The participants in the study were 50 teachers from different secondary schools in Duhok, 25 of whom were females and 25 males. The selected secondary school teachers volunteered to participate in the study as interviewees.

All of the teachers were native speakers of Kurdish and had a BA degree in English language; however, they differed in their background of teaching experience: some had many years of teaching experience, while others had a shorter experience (Table 1).

Table 1

The distribution of the teachers according to their teaching experience

\begin{tabular}{ll}
\hline \hline Experience & Number of teachers \\
\hline 1-5 years & 12 \\
5-10 years & 10 \\
10-15 years & 19 \\
More than 15 years & 9 \\
\hline \hline
\end{tabular}

\subsection{Instruments}

The study employed interview as a research tool. Fifty teachers were interviewed. The purpose of the interview was to collect qualitative data. The interview consisted of 6 questions and each interview lasted for about 15 to 20 minutes. Notes were taken during the interviews, and were audio recorded and later transcribed for the analysis of the study. The questions were prepared in a way to help the researcher to identify where and for what purpose the teachers used Kurdish while teaching English.

Before starting the interview, which was carried out in English and/or Kurdish as was preferred by the interviewee, all the participants were informed about the purpose of the research. The questions were predetermined; nevertheless, the interviews consisted of open-ended and close-ended questions. During the interviews, it was necessary for the researcher to assure the teachers that the interview was not to judge their teaching or their attitudes towards L1/L2 use. This was 
done to avoid bias in which case, the teachers might change their behavior and answer in order to fulfil the perceived requirement of the research.

\section{Results and discussion}

\subsection{Results}

In general, the data collected revealed that the majority of the teachers (94\%) use Kurdish in their English language classes. Table 2 summarizes the interview questions and the results obtained for each question in percentages.

Table 2

Teachers view on the use of Kurdish in the classroom.

\begin{tabular}{|c|c|}
\hline Statements & Percentage \\
\hline \multicolumn{2}{|l|}{$\begin{array}{l}\text { Do you think Kurdish should be used in the English } \\
\text { classroom at secondary school or not? }\end{array}$} \\
\hline Yes & 60 \\
\hline No & 40 \\
\hline \multicolumn{2}{|l|}{ Do you yourself as a teacher use L1 (Kurdish) in } \\
\hline Yes & 6 \\
\hline \multicolumn{2}{|l|}{ No } \\
\hline \multicolumn{2}{|l|}{ For what purposes do you use Kurdish? } \\
\hline - $\quad$ grammatical points & 47.9 \\
\hline - $\quad$ new vocabularies & 31.5 \\
\hline - $\quad$ clarifying difficult concepts or ideas & 15.1 \\
\hline giving instructions & 5.5 \\
\hline \multicolumn{2}{|l|}{$\begin{array}{l}\text { On what basis do you decide to use Kurdish (L1) in } \\
\text { the English classroom at secondary level? }\end{array}$} \\
\hline - school's policy or students' needs & 27.8 \\
\hline - based on the lesson content & 26.7 \\
\hline - based on experience & 25.6 \\
\hline - based on the current thinking in methodology & 8.9 \\
\hline - intuitively & 6.7 \\
\hline - based on code switching. & 4.4 \\
\hline \multirow{2}{*}{\multicolumn{2}{|c|}{$\begin{array}{l}\text { Do you think using L1 (Kurdish) facilitates or } \\
\text { hinders the teaching of English language in the } \\
\text { classroom? }\end{array}$}} \\
\hline & \\
\hline Facilitate & 18 \\
\hline Hinder & \\
\hline
\end{tabular}

The results show that the use of Kurdish is reasonable in the English classroom. Teachers stated that L1 facilitates teaching and they mainly use it for explaining grammar points, new vocabularies, clarifying new concepts or ideas and giving instructions.

\subsection{Discussion}

The results of the current study revealed the majority of the teachers (94\%) who participated in this research used Kurdish in their English language classes and (82\%) reflected their positive view towards its use. The use of Kurdish proved to facilitate many things in the English language class, such as $47.9 \%$ use L1 for teaching grammatical points, $31.5 \%$ use it while teaching new vocabularies, $15.1 \%$ for clarifying difficult concepts or ideas, and $5.5 \%$ for giving instructions.

The findings of the current study are coherent with the results of Oflaz (2009) that the learners found the role of L1 to be supportive; therefore, these findings too give support to the use of L1 in classroom. The results are also consistent with those of Al-Nofaie (2010), Alshammari (2011), Schweers (1999) and Tang (2002) which showed that both teachers and students responded positively to the use of L1. However, the results are contradictory to those of Nazary (2008) who reported on the Iranian learners' reluctance to use L1.

Nevertheless, through direct discussion with teachers it could be realized that most of them would agree that a limited use of L1 is more efficient for achieving comprehension of FL. In addition, the teachers also indicated that L1 should not be overused, but should be used whenever necessary only, i.e. judiciously.

\section{Conclusion}

In teaching English in EFL contexts, most of the teachers feel the necessity to use first language (L1); however, they should be aware whether using L1 would facilitate or hinder the teaching and learning of FL. This study aimed at determining whether or not the use of L1 facilitates or hinders the learning of FL in secondary school EFL classes in Duhok. Moreover, it investigated for what purposes they use it and on what basis they 
decide to use it. The findings support that the use of L1 facilitates teaching and learning of FL. Furthermore, teachers mostly tend to fall back to L1 for teaching grammar and vocabulary.

Lastly, the findings of this study confirm previous research on the role of L1 in EFL classes, and contribute additional evidence which relates to the possibility of determining how much and when L1 is most useful for EFL students in the classroom.

\section{Bibliography}

1. Alshammari, M. M. (2011). The use of the mother tongue in Saudi EFL classrooms. Journal of International Education Research, 4(1), 64-95.

2. Atkinson, D. (1993). Teaching monolingual classes. London: Longman.

3. AL-Nofaie, H. (2010). The attitudes of teachers and students towards using Arabic in EFL classrooms in Saudi public schools - a case study. Novitas-Royal, 4(1), 64-95.

4. Carless, D. (2001). Implementing task-based learning with young learners. In ELT Journal, 46 (4).

5. Cook, V. (2001). Using the first language in the classroom. Canadian Modern Language Review, 57(3), 402-423.

6. Harbord, J. (1992). The use of mother tongue in the classroom. ELT Journal, 46 (4).

7. Hawks, P. (2001). Making distinction: A discussion of the mother tongue in the foreign language classroom. Hwa Kang Journal of TEFL, 7, (47-55).

8. James, C. (1998). Errors in language learning and use: Exploring error analysis. London: Longman.

9. Krashen, S. D. (1985). The Input hypothesis and implication. London: Longman.

10. Kurdistan (2013). A Summary on Kurdistan Regional Government, Retrieved from http://www.sunrisekurdistan.com

11. Macaro, E. (1997). Target language, collaborative learning and autonomy. Clevedon: Multilingual Matters.

12. Nazary, M. (2008). The role of L1 in L2 acquisition: Attitudes of Iranian university students. Novitas Royal, 2(2), 138-153.

13. Odlin, T. (1989). Language transfer: Cross-linguistic influence in language teaching. London: Cambridge University Press.

14. Oflaz, Ö. (2009). Teachers and students' views on using mother tongue in ELT classrooms (A case study at Gaziantep University.)

15. Phillipson, R. (1992). Linguistic imperialism. Oxford University Press: Oxford.

16. Pokharel, B. R. (2001). Applied Linguistics. Kathmandu: Jupiter Publishers and Distributors.
17. Schweers, W. Jr. (1999). Using L1 in the L2 classroom. English Teaching Forum, 37 (2), 6-9.

18. Tang, J. (2002). Using L1 in the English classroom. English Teaching Forum, 40 (1), 36-43. 


\section{Appendix 1 \\ Interview for Teachers}

(Please try to answer all the questions applicable to your situation)

I am an MA student at the English Department, College of Languages, University of Duhok. I am doing a research under the title of 'Evaluating the Use of L1 in EFL Classes at Selected Secondary Schools in Duhok City'.

This interview is to find out when teachers' use L1 (Kurdish language in this case) in secondary English as a foreign language (EFL) classrooms. It also aims at evaluating the use of L1 in EFL classes at secondary schools in Duhok city.

It is not a test and there are not correct or incorrect answers. Your personal and sincere answers will be appreciated. I assure your responses will be treated with the utmost confidentiality in accordance with research ethics. Thank you for your kind cooperation and participation.

Researcher

Hamza Y. Omer

1. Please indicate:

\begin{tabular}{|l|l|}
\hline Grade & \\
\hline Gender & \\
\hline Date & \\
\hline Your Native Language & \\
\hline
\end{tabular}

2. How many years have you been teaching English?

a) 1-5 years

b) 5-10 years

c) $10-15$ years

d) More than 15 years

3. Do you think Kurdish should be used in the English classroom at secondary school or not?

4. Do you yourself as a teacher use L1 (Kurdish) in your class? If yes, for what purposes do you use Kurdish for?

5. On what basis do you decide to use Kurdish (L1) in the English classroom at secondary level? (Select all that apply)

- Intuitively

- Based on the lesson content

- Based on experience

- Following the current thinking in methodology

- Based on an established school's policy or Based on students' needs

- Code-switching

- Other (please, specify)

6. Do you think using L1 (Kurdish) facilitates or hinders the teaching of English language in the classroom? 